\title{
Public Governance and Economic Growth of Non-Oil-Exporting Arab Countries
}

\author{
Elham Mohammad Alhaj Yousef \\ Business Economics Department, Faculty of Business, University of Jordan, Amman, Jordan
}

Email address:

Ehajsuper1@hotmail.com

To cite this article:

Elham Mohammad Alhaj Yousef. Public Governance and Economic Growth of Non-Oil-Exporting Arab Countries. International Journal of Business and Economics Research. Vol. 9, No. 4, 2020, pp. 183-191. doi: 10.11648/j.ijber.20200904.14

Received: April 26, 2020; Accepted: June 1, 2020; Published: June 17, 2020

\begin{abstract}
This paper aims at investigating the impact of public governance on the economic growth in Non-Oil-Exporting Arab countries (NOEAC). The study used panel data for six NOEAC over the period from 1998 to 2017. Some study variables were not stationary at level but they became stationary after taking the first difference for them. The result of applying Kao panel cointegration test revealed that the study model was cointegrated. Therefore, Fully Modified Ordinary Least Squares (FMOLS) model was applied for estimation showing that governance factors have the greatest significant positive effects on the economic growth in such countries. Gross fixed capital formation, labor force growth rate, trade openness, economic freedom, rule of law, regulatory quality, control of corruption, and voice and accountability have statistically significant positive impact on their economic growth during the study period, while the Global Financial Crisis of 2008 (GFC) with its slow recovery has a significant negative impact on their economic growth. Political stability and government effectiveness have insignificant effects. The main conclusion derived from this paper is that political and institutional aspects can play an important role in the economic progress, and they are responsible for major contribution to economic growth and development. Therefore, attracting domestic and foreign direct investments, increasing labor and capital productivities, strengthening governance, improving public administration and eradication of corruption have the first priorities in NOEAC.
\end{abstract}

Keywords: Governance, Economic Growth, Economic Freedom, Trade Openness

\section{Introduction}

The economic growth is the basis for achieving economic development, therefore, all countries actively try to adopt the suitable policies to boost their gross national income, raise education standards, fight poverty, reduce unemployment, increase investments and support technological progress and innovation. There are mainly two types of the determinants of economic growth: 1- Economic factors that have a direct impact on production process such as gross capital formation, workforce, natural resources, technological progress, the nature of foreign trade and economic system. 2- NonEconomic factors that indirectly affect the economic progress through influencing the behaviour of societies, such as; the role and the structure of government, corruption, political stability, culture, traditions, religion etc. In fact, the NonEconomic factors have been commonly used in economic development studies related to the third world countries during the last sixty years. Kindleberger [1] presented some non-economic factors such as family, class, culture, race, religion etc. It should be noted that these economic and noneconomic factors substantially interact with each other.

This study explores and analyzes the impact of the main factors on economic growth of NOEAC using panel data for six NOEAC over the period of 1998-2017. It also sheds light on the importance of non-economic factors as overwhelming determinants and responsible for major contribution to economic growth of such countries, which ultimately help to draw some recommendations. It is then wished that policy makers would take them into account when they are applying their policies.

\section{The Problem of the Study}

Arab countries actually suffer from low growth rates of their real gross domestic product (RGDP), and they are facing pressures to get the economy functioning in a normal manner. This issue was the motive for many economists and 
researchers to conduct several studies in order to explore the main determinants of economic growth and development. Therefore, the problem of this study can be considered as one of these studies in which it tries to answer the question of what are the main factors that could significantly impact the economic growth of selected NOEAC.

\section{Objective of the Study}

The main objective of this study is to investigate the impact of gross fixed capital formation (GFCF), labor force growth rate, economic freedom, trade openness and six governance indicators on the economic growth of selected NOEAC over the period 1998-2017.

\section{Limitations of the Study}

This study investigates the impact of some non-economic factors because other ones (such as, culture, traditions, race and religion) have subjective indicators that may distort the results or their reading. Some NOEAC were excluded from the sample because of the unavailability of all required data during the study period. Therefore, the impact of the main factors on economic growth of six NOEAC over the period from 1998 to 2017 will only be tested.

\section{Hypothesis of the Study}

The paper aims at testing the following main null hypothesis: There is no significant relationship between RGDP growth rate of NOEAC and each of: GFCF to GDP ratio, labor force growth rate, economic freedom, trade openness, voice and accountability, political stability, government effectiveness, regulatory quality, control of corruption and rule of law.

\section{Literature Review}

Adam Smith has analyzed economic growth issues in his book "The Wealth of Nations", in which he emphasized that savings, division of work and specialization are the most important determinants of the economic growth; savings lead to capital accumulation, while division of work and specialization boost productivity levels which in turn increase wages and profits. Some of these profits could be saved in order to raise investments until economic progress can ultimately be achieved. In the recent years, the theory of economic growth presented by neoclassical model of Solow depends on many assumptions such as constant return to scale production function, diminishing marginal productivity of capital, perfect competition, producing one homogenous good, savings equals investments [2]. His exogenous variables are: saving rate, population growth rate and technological progress rate. He stressed that saving rate is the main determinant of economic growth in the short-run, while technological progress is the most important one in the longrun.
Recently, Romer [3] and Lucas [4] have considered technological progress as an endogenous variable and the main determinant of economic growth in the long-run. They have actually determined three major sources of economic growth: innovation, new knowledge and public infrastructure. They also have introduced the endogenous growth theory which beats diminishing returns law, and states that investing in capital, labor, research and development, technology and education skills will increase labor productivity which eventually enhance the economic performance. On the same line, Romer [5] has presented the augmented Solow model which emphasized that the economy could infinitely continue to grow. On the other hand, Barro found that policies could enhance and boost the long-run economic growth [6, 7]. Other studies have emphasized the significant role of institutions in the economic growth $[8,9,10]$. Some researchers have also investigated the impact of many socialcultural factors (race, culture, language, religion, attitudes) on economic growth $[11,12]$. Others emphasized the role of some non-economic factors, such as political factors, geography and demography [13, 14]. They stressed that political instability could increase uncertainty which eventually reduce investments and economic progress. Moreover, Barro [7] has tested the impact of some demographic factors (migration, population growth, age distribution, population density) on economic growth, but the results were not conclusive.

In fact, neoclassical and endogenous growth models emphasized the significant role of investment in economic growth which led to the emergence of many of studies that investigated the relationship between investment and economic growth [13, 15]. In addition, Lensink and Morrissey highlighted the significant role of foreign direct investment in technology transfer and economic growth [16]. The impact of human capital has also been investigated by Barro and others who found a significant positive relationship between educated and skilled labor and economic growth [6, 17]. Endogenous growth models have actually emphasized the vital role of innovation, technology, research and development in increasing productivity and then economic growth $[18,19]$. All economic theories agree that improving business climate is very important in attracting national and foreign investments, which ultimately will boost economic growth. Investors stay away from a politically instable, highly corrupted and bureaucratic countries, in which their governments are not delivering public services efficiently and transparently [20, 21, 22].

Dollar and Kraay affirmed that trade openness has a significant positive effect on economic growth through exploiting comparative advantages and permitting technology transfer and competition [23, 24]. Similarly, AlRaimony explored the economic growth determinants in Jordan by using the aggregate Cobb Douglas production function [25]. He found that RGDP growth rate has positive relationship with real capital and export growth rates, but it has negative relationship with labor and import growth. Razmi and Refaei used panel data approach to investigate the 
effects of trade openness and economic freedom on economic growth of 17 Middle East and East Asian countries during the period of 2000-2009 [26]. They proved that trade openness and economic freedom have significant positive impact on economic growth. On the other hand, Lahouij used panel data for selected oil-importing Middle East and North Africa countries during the period 2002-2013, and found that governance is strongly associated with the economic development [27]. In addition, Petrakos, et al. conducted a questionnaire survey in order to explore experts' views on the main determinants of economic growth [28]. They found that political and institutional factors have the prevailed effects on economic growth of developing countries, while the parameters with more economic, hi-tech and specialized features significantly affect the growth of developed countries. Furthermore, Bayar used panel data for transitional economies of the European Union over the period of 20022013 in order to investigate the impact of six governance indicators on their economic growth [29]. He found that all governance indicators (except regulatory quality) have significant positive effects on economic growth. Edlund also used panel data for 48 middle-income countries over the period of 2000-2014, in order to test the impact of economic freedom on the economic growth of such countries [30]. This study found that economic freedom, legal system and property rights have significant positive effects on economic growth, while inflation has a significant negative impact on such growth.

\section{Data and Variables Description}

The study assumes that NOEAC are the countries that have (on average) less than fifty percent of its total exports as oil exports. The ratios of annual oil exports/total exports for each Arab country were extracted from World Bank database. Based on these ratios, the study considered Jordan, Lebanon, Morocco, Sudan, Tunisia and Egypt as NOEAC. The annual data for such countries over the period 1998-2017 was used. The study used panel approach because it has greater degrees of freedom and less multicollinearity which give more efficient estimates and control for unobserved heterogeneity [31]. All the data (except economic freedom) were taken from World Bank database which are calculated in US dollar (more stable than other currencies) helping to achieve consistency. The description of the variables is as follows:

YG (dependent variable): the annual growth rate of RGDP as a proxy for economic growth. It is the percentage annual change in RGDP. GDP is the market value of all final goods and services produced within country's borders in a specific time period (usually on an annual basis). Economic growth is influenced by various direct factors (e.g. human capital, natural resources, fixed capital, technological progress) and indirect factors (e.g. institutions, public polices, aggregate demand size, efficiency of financial system).

The independent variables are:

1- KF: GFCF to GDP ratio as a proxy for annual gross fixed capital accumulation for a country that measures the value of acquisitions of new or existing assets by both private sector and government (without deducting the depreciation of fixed assets). The economic theory emphasized that countries need capital goods to replace the current assets that are used in production, and if a country cannot replace capital goods, production declines. 2- LF: labor force growth rate as the percentage change in an economy's labor force. Labor force is the number of people who are at or above the age of 16 , and either employed or actively looking for work. People who do not want to work or can't work (students, homemakers, disabled, incarcerated people, retirees) are not included in the labor force. The economic theory assured the positive effect of labor force on economic growth. 3- OT: Openness to trade as a proxy of economic policies that either restrict or invite trade between countries. Fewer restrictions on trade can foster economic trade. Trade openness is actually measured by various methods, but this study uses the sum of exports and imports to the country's GDP as its index. The higher the index the larger is the trade openness and the stronger is the economy. 4- EF: Aggregate index for economic freedom as a proxy for the ability of all individuals in a society to undertake their own economic actions or to protect their liberty to pursue their own economic interests. The higher the index the greater is the economic freedom and the greater is the prosperity. The study uses an annual index created by The Heritage Foundation and The Wall Street Journal in 1995. This index measures the degree of freedom in investment, trade, business, financial and monetary markets. The index varies between 0 (the least free) and 100 (the most free). 5Public Governance as the way in which authority and power is used in the management of a country's economic and social resources for development [32]. This governance determines how public decisions are designed and applied. It is measured by six Worldwide Governance Indicators that are obtained from World Bank Governance Indicators (WGI). Such indicators are based on 31 data sources reporting the perceptions of governance held by many survey respondents and expert assessments worldwide. These indicators vary between -2.5 (weakest) and 2.5 (strongest) governance performance. The definitions of these indicators are extracted from WGI: VA: Voice and accountability measures the extent to which a country's citizens are able to participate in selecting their government, as well as freedom of expression and a free media. PS: Political stability measures the likelihood that the government will be destabilized or overthrown by unconstitutional or violent means. RQ: Regulatory quality measures the ability of the government to formulate and implement sound policies and regulations that promote private sector development. GE: Government effectiveness measures the quality of public and civil services, the degree of its independence from political pressures, the quality of policy formulation and implementation, and the credibility of the government's commitment to such policies. $\mathrm{CC}$ : Control of corruption measures the extent to which public power is used and exercised for private gains, as well as capture of the state by elites and private interests. RL: 
Rule of law measures the extent to which agents have confidence in and abide by the rules of the country, in particular the quality of contract enforcement, property rights, courts and police. 6- DM: A dummy variable that indicates the absence or the presence of GFC of 2008 and its slow recovery afterwards. It takes the value of 1 during the period of 2008-2012, otherwise it takes the value 0. Such variable is used because GFC which is out of the control of Arab countries may conceal the expected positive impact of institutional reforms or any development in governance.

\section{Methodology}

The study uses Cobb-Douglas production function which is commonly used to represent the technological relationship between the amounts of inputs, and the amount of output that can be produced by such inputs. This production function was developed and tested against statistical evidence by Charles Cobb and Paul Douglas in 1928, and their studies became the motive for many researchers to conduct several studies (both at individual and institutional levels) in order to investigate the determinants of economic growth. Starting with:

$$
\mathrm{Y}_{\mathrm{t}}=\mathrm{A}_{\mathrm{t}} \mathrm{K}_{\mathrm{t}}^{\alpha} \mathrm{L}_{\mathrm{t}}^{\beta}
$$

$\mathrm{Y}_{\mathrm{t}}$ : RGDP at time t. $\mathrm{K}$ and $\mathrm{L}$ are capital and labor (respectively) as production inputs during the same period $t$. A is total factor productivity or technological progress at time t. Equation 1 could be extended as follows:

$$
\mathrm{Y}_{\mathrm{t}}=\mathrm{A}_{\mathrm{t}} \mathrm{K}_{\mathrm{t}}^{\alpha} \mathrm{L}_{\mathrm{t}}^{\beta} \mathrm{O}_{\mathrm{t}}^{\varphi} \mathrm{E}_{\mathrm{t}}^{\mathrm{C}}
$$

$\mathrm{O}$ is trade openness at time t. $\mathrm{E}$ is economic freedom at time $\mathrm{t}$, while $\alpha, \beta, \varphi$ and $\epsilon$ represent the output elasticity of capital, labor, trade openness and economic freedom respectively. After taking the logarithm of both sides of equation (2) it becomes as follows:

$$
\log \mathrm{Y}_{\mathrm{t}}=\log \mathrm{A}_{\mathrm{t}}+\alpha \log \mathrm{K}_{\mathrm{t}}+\beta \log \mathrm{L}_{\mathrm{t}}+\varphi \log \mathrm{O}_{\mathrm{t}}+C \log \mathrm{E}_{\mathrm{t}}(3)
$$

Taking the logarithm of both sides of equation (1) then differentiating with respect to time both sides, it becomes as follows:

$$
\mathrm{YG}_{\mathrm{t}}=\mathrm{AG}_{\mathrm{t}}+\alpha \mathrm{KG}_{\mathrm{t}}+\beta \mathrm{LG}_{\mathrm{t}}
$$

YG: the growth rate of RGDP at time t. AG: the growth rate of technological progress (Solow residual). KG: the growth rate of capital at time t. LG: labor force growth rate at time $t$. It is known that the time derivative of the logarithm of any variable is the growth rate of that variable. Equation 4 can be estimated as follows:

$$
\mathrm{YG}_{\mathrm{t}}=\mathrm{c}+\alpha \mathrm{KG}_{\mathrm{t}}+\beta \mathrm{LG}_{\mathrm{t}}+\mathrm{e}_{\mathrm{t}}
$$

(c: constant or intercept, $\mathrm{e}_{\mathrm{t}}$ : error term)

Based on the previous analysis and the previous studies such as Bayar [29] and [33], Emara and Jhonsa [34], Bouoiyour and Naimbayel [35], Fayissa and Nsiah [36], Pere
[22], Orayo and Mose [37], Lahouij [27], Onyinye, et al. [38], Josheski, et al. [39], Razmi and Refaei [26] and Berggren and Jordahl [40], this study will estimate the following regression model:

$$
\begin{gathered}
\mathrm{YG}_{\mathrm{it}}=\beta_{0}+\beta_{1} \mathrm{KF}_{\mathrm{it}}+\beta_{2} \mathrm{LF}_{\mathrm{it}}+\beta_{3} \mathrm{OT}_{\mathrm{it}}+\beta_{4} \mathrm{EF}_{\mathrm{it}}+\beta_{5} \mathrm{VA}_{\mathrm{it}}+\beta_{6} \\
\mathrm{PS}_{\mathrm{it}}+\beta_{7} \mathrm{GE}_{\mathrm{it}}+\beta_{8} \mathrm{RQ}_{\mathrm{it}}+\beta_{9} \mathrm{RL}_{\mathrm{it}}+\beta_{10} \mathrm{CC}_{\mathrm{it}}+\lambda \mathrm{DM}_{\mathrm{it}}+\mathrm{u}_{\mathrm{it}}(6)
\end{gathered}
$$

Where $\beta_{0}$ : intercept, $\mathrm{i}$ : country, $\mathrm{t}$ : year, $\mathrm{u}_{\mathrm{it}}$ : random error term, YG: growth rate of RGDP, KF: gross fixed capital formation to GDP ratio, LF: labor force growth rate, OT: trade openness that is measured by the sum of exports and imports to GDP ratio, and EF: economic freedom index. Governance variables are: VA: voice and accountability, PS: political stability, GE: government effectiveness, RQ: regulatory quality, RL: rule of law, and $\mathrm{CC}$ : control of corruption. DM: a dummy variable that indicates the absence or the presence of GFC of 2008 with its slow recovery (during GFC and its slow recovery (2008-2012) is one, otherwise is zero). According to the literature and the previous studies, the expected signs of all coefficients except that of DM are to be positive.

\section{Empirical Results}

The empirical analysis begins with the unit root tests in order to avoid spurious relationships. The study uses Levin, Lin and Chu, Im, Pesaran and Shin W-stat, ADF-Fisher Chisquare, PP-Fisher Chi-square and Breitung t-stat to test for the existence of unit roots in the panel data. The results of testing the null hypotheses of existing unit roots for the study variables at both individual effects level and individual effects and individual linear trends level are presented in tables 1 and 2 respectively. The null hypothesis for such test: panel data has a unit root (or not stationary). If the probability value is less than $5 \%$, the null hypothesis will be rejected, meaning that the variable is stationary at level, but if it is more than $5 \%$, the null hypothesis will not be rejected, meaning that the variable is not stationary at level. The decision is made based on the majority of the test methods' results when the results are mixed. According to tables $1 \& 2$, the variables $\mathrm{KF}$, OT, PS and CC are not stationary at both the level of individual effects and the level of individual effects and individual linear trends, because the majority of the probability values are more than $5 \%$ for these variables at both levels. Therefore the null hypotheses of existing unit roots are accepted for these variables. Meanwhile, RL is not stationary at the level of individual effects but stationary at the level of individual effects and individual linear trends. In contrast, VA is stationary at the level of individual effects but not stationary at the level of individual effects and individual linear trends. On the other hand, YG, LF, EF, RQ and GE are stationary at such levels because the majority of their probability values are less than $5 \%$, indicating that the null hypotheses of existing unit roots are rejected for such variables. 
Table 1. Panel unit root test: Level of individual effects.

\begin{tabular}{|c|c|c|c|c|c|}
\hline Variable & Exogenous variables & Method & Statistic value & Prob. value & decision \\
\hline \multirow{4}{*}{ YG } & \multirow{4}{*}{ Individual effects } & Levin, Lin\& Chu & -3.95114 & 0.0000 & Stationary \\
\hline & & IM, Pesaran and Shin W-stat & -3.81203 & 0.0001 & Stationary \\
\hline & & ADF-Fisher Chi-square & 37.5254 & 0.0002 & Stationary \\
\hline & & PP- Fisher Chi-square & 34.4116 & 0.0006 & Stationary \\
\hline \multirow{4}{*}{ LF } & \multirow{4}{*}{ Individual effects } & Levin, Lin\& Chu & -3.43275 & 0.0003 & Stationary \\
\hline & & IM, Pesaran and Shin W-stat & -3.64946 & 0.0001 & Stationary \\
\hline & & ADF-Fisher Chi-square & 35.2437 & 0.0004 & Stationary \\
\hline & & PP- Fisher Chi-square & 36.6756 & 0.0003 & Stationary \\
\hline \multirow{4}{*}{ KF } & \multirow{4}{*}{ Individual effects } & Levin, Lin\& Chu & 0.47164 & 0.6814 & Non stationary \\
\hline & & IM, Pesaran and Shin W-stat & -0.38283 & 0.3509 & Non Stationary \\
\hline & & ADF-Fisher Chi-square & 12.5959 & 0.3991 & Non Stationary \\
\hline & & PP- Fisher Chi-square & 13.0827 & 0.3631 & Non Stationary \\
\hline \multirow{4}{*}{$\mathrm{EF}$} & \multirow{4}{*}{ Individual effects } & Levin, Lin\& Chu & -3.66409 & 0.0001 & Stationary \\
\hline & & IM, Pesaran and Shin W-stat & -2.74719 & 0.0030 & Stationary \\
\hline & & ADF-Fisher Chi-square & 28.9814 & 0.0040 & Stationary \\
\hline & & PP- Fisher Chi-square & 156.051 & 0.0000 & Stationary \\
\hline \multirow{4}{*}{ OT } & \multirow{4}{*}{ Individual effects } & Levin, Lin\& Chu & -2.54673 & 0.0054 & Stationary \\
\hline & & IM, Pesaran and Shin W-stat & -1.32532 & 0.0925 & Non Stationary \\
\hline & & ADF-Fisher Chi-square & 16.7985 & 0.1573 & Non Stationary \\
\hline & & PP- Fisher Chi-square & 7.58835 & 0.8164 & Non Stationary \\
\hline \multirow{4}{*}{ VA } & \multirow{4}{*}{ Individual effects } & Levin, Lin\& Chu & -3.14023 & 0.0008 & Stationary \\
\hline & & IM, Pesaran and Shin W-stat & -2.19012 & 0.0143 & Stationary \\
\hline & & ADF-Fisher Chi-square & 25.9120 & 0.0110 & Stationary \\
\hline & & PP- Fisher Chi-square & 22.1528 & 0.0358 & Stationary \\
\hline \multirow{4}{*}{ GE } & \multirow{4}{*}{ Individual effects } & Levin, Lin\& Chu & -9.36943 & 0.0000 & Stationary \\
\hline & & IM, Pesaran and Shin W-stat & -5.43685 & 0.0000 & Stationary \\
\hline & & ADF-Fisher Chi-square & 64.9643 & 0.0000 & Stationary \\
\hline & & PP- Fisher Chi-square & 27.6025 & 0.0063 & Stationary \\
\hline \multirow{4}{*}{ PS } & \multirow{4}{*}{ Individual effects } & Levin, Lin\& Chu & -0.40161 & 0.3440 & Non Stationary \\
\hline & & IM, Pesaran and Shin W-stat & 0.26564 & 0.6047 & Non Stationary \\
\hline & & ADF-Fisher Chi-square & 12.4633 & 0.4092 & Non Stationary \\
\hline & & PP- Fisher Chi-square & 14.1764 & 0.2896 & Non Stationary \\
\hline \multirow{4}{*}{ RQ } & \multirow{4}{*}{ Individual effects } & Levin, Lin\& Chu & -2.55409 & 0.0053 & Stationary \\
\hline & & IM, Pesaran and Shin W-stat & -3.08513 & 0.0010 & Stationary \\
\hline & & ADF-Fisher Chi-square & 32.9567 & 0.0010 & Stationary \\
\hline & & PP- Fisher Chi-square & 18.2516 & 0.1083 & Non Stationary \\
\hline \multirow{4}{*}{ RL } & \multirow{4}{*}{ Individual effects } & Levin, Lin\& Chu & -1.70280 & 0.0443 & Stationary \\
\hline & & IM, Pesaran and Shin W-stat & -1.00459 & 0.1575 & Non Stationary \\
\hline & & ADF-Fisher Chi-square & 17.3776 & 0.1359 & Non Stationary \\
\hline & & PP- Fisher Chi-square & 17.3389 & 0.1373 & Non Stationary \\
\hline \multirow{4}{*}{$\mathrm{CC}$} & \multirow{4}{*}{ Individual effects } & Levin, Lin\& Chu & -2.45606 & 0.0070 & Stationary \\
\hline & & IM, Pesaran and Shin W-stat & -1.42262 & 0.0774 & Non Stationary \\
\hline & & ADF-Fisher Chi-square & 17.6710 & 0.1261 & Non Stationary \\
\hline & & PP- Fisher Chi-square & 20.9564 & 0.0510 & Non Stationary \\
\hline
\end{tabular}

Source: Author's calculation.

Table 2. Panel unit root test: Level of individual effects and individual linear trends.

\begin{tabular}{|c|c|c|c|c|c|}
\hline Variable & Exogenous variables & Method & Statistic value & Prob. value & decision \\
\hline \multirow{5}{*}{ YG } & \multirow{5}{*}{$\begin{array}{l}\text { Individual effects \& } \\
\text { individual linear trends }\end{array}$} & Levin, Lin\& Chu & -2.97071 & 0.0015 & Stationary \\
\hline & & Breitung t-stat & -2.04731 & 0.0203 & Stationary \\
\hline & & IM, Pesaran and Shin W-stat & -2.08954 & 0.0183 & Stationary \\
\hline & & ADF-Fisher Chi-square & 25.4415 & 0.0129 & Stationary \\
\hline & & PP- Fisher Chi-square & 25.8543 & 0.0113 & Stationary \\
\hline \multirow{4}{*}{ LF } & \multirow{4}{*}{$\begin{array}{l}\text { Individual effects \& } \\
\text { individual linear trends }\end{array}$} & Levin, Lin\& Chu & -3.47346 & 0.0003 & Stationary \\
\hline & & Breitung t-stat & -3.35419 & 0.0004 & Stationary \\
\hline & & ADF-Fisher Chi-square & 25.8015 & 0.0114 & Stationary \\
\hline & & PP- Fisher Chi-square & 36.2859 & 0.0003 & Stationary \\
\hline \multirow{5}{*}{ KF } & \multirow{5}{*}{$\begin{array}{l}\text { Individual effects \& } \\
\text { individual linear trends }\end{array}$} & Levin, Lin\& Chu & 0.62928 & 0.7354 & Non Stationary \\
\hline & & Breitung t-stat & 0.68252 & 0.7525 & Non Stationary \\
\hline & & IM, Pesaran and Shin W-stat & 1.16041 & 0.8771 & Non Stationary \\
\hline & & ADF-Fisher Chi-square & 6.53037 & 0.8870 & Non Stationary \\
\hline & & PP- Fisher Chi-square & 7.23756 & 0.8415 & Non Stationary \\
\hline
\end{tabular}




\begin{tabular}{|c|c|c|c|c|c|}
\hline Variable & Exogenous variables & Method & Statistic value & Prob. value & decision \\
\hline \multirow{5}{*}{$\mathrm{EF}$} & \multirow{5}{*}{$\begin{array}{l}\text { Individual effects \& } \\
\text { individual linear trends }\end{array}$} & Levin, Lin\& Chu & -3.37906 & 0.0004 & Stationary \\
\hline & & Breitung t-stat & -1.82873 & 0.0337 & Stationary \\
\hline & & IM, Pesaran and Shin W-stat & -2.22765 & 0.0130 & Stationary \\
\hline & & ADF-Fisher Chi-square & 21.8725 & 0.0158 & Stationary \\
\hline & & PP- Fisher Chi-square & 13.3787 & 0.2033 & Non Stationary \\
\hline \multirow{5}{*}{ OT } & \multirow{5}{*}{$\begin{array}{l}\text { Individual effects \& } \\
\text { individual linear trends }\end{array}$} & Levin, Lin\& Chu & -1.07690 & 0.1408 & Non Stationary \\
\hline & & Breitung t-stat & 0.30953 & 0.6215 & Non Stationary \\
\hline & & IM, Pesaran and Shin W-stat & 0.65978 & 0.7453 & Non Stationary \\
\hline & & ADF-Fisher Chi-square & 7.57702 & 0.8173 & Non Stationary \\
\hline & & PP- Fisher Chi-square & 3.77994 & 0.9871 & Non Stationary \\
\hline \multirow{5}{*}{ VA } & \multirow{5}{*}{$\begin{array}{l}\text { Individual effects \& } \\
\text { individual linear trends }\end{array}$} & Levin, Lin\& Chu & -2.35290 & 0.0093 & Stationary \\
\hline & & Breitung t-stat & -0.43836 & 0.3306 & Non Stationary \\
\hline & & IM, Pesaran and Shin W-stat & -0.85445 & 0.1964 & Non Stationary \\
\hline & & ADF-Fisher Chi-square & 16.4673 & 0.1708 & Non Stationary \\
\hline & & PP- Fisher Chi-square & 15.4259 & 0.2190 & Non Stationary \\
\hline \multirow{5}{*}{ GE } & \multirow{5}{*}{$\begin{array}{l}\text { Individual effects \& } \\
\text { individual linear trends }\end{array}$} & Levin, Lin\& Chu & -11.7574 & 0.0000 & Stationary \\
\hline & & Breitung t-stat & -0.34289 & 0.3658 & Non Stationary \\
\hline & & IM, Pesaran and Shin W-stat & -6.58503 & 0.0000 & Stationary \\
\hline & & ADF-Fisher Chi-square & 50.6089 & 0.0000 & Stationary \\
\hline & & PP- Fisher Chi-square & 20.6786 & 0.0553 & Non Stationary \\
\hline \multirow{5}{*}{ PS } & \multirow{5}{*}{$\begin{array}{l}\text { Individual effects \& } \\
\text { individual linear trends }\end{array}$} & Levin, Lin\& Chu & -1.28586 & 0.0992 & Non Stationary \\
\hline & & Breitung t-stat & -0.54846 & 0.2917 & Non Stationary \\
\hline & & IM, Pesaran and Shin W-stat & -2.23769 & 0.0126 & Stationary \\
\hline & & ADF-Fisher Chi-square & 25.9025 & 0.0111 & Stationary \\
\hline & & PP- Fisher Chi-square & 15.2320 & 0.2290 & Non Stationary \\
\hline \multirow{6}{*}{ RQ } & \multirow{6}{*}{$\begin{array}{l}\text { Individual effects \& } \\
\text { individual linear trends }\end{array}$} & Levin, Lin\& Chu & -2.44149 & 0.0073 & Stationary \\
\hline & & Breitung t-stat & -2.36090 & 0.0091 & Stationary \\
\hline & & IM, Pesaran and Shin W-stat & -2.39049 & 0.0084 & Stationary \\
\hline & & ADF-Fisher Chi-square & 25.8126 & 0.0114 & Non Stationary \\
\hline & & PP- Fisher Chi-square & 13.3380 & 0.3450 & Stationary \\
\hline & & Levin, Lin\& Chu & -3.37619 & 0.0004 & Stationary \\
\hline \multirow{4}{*}{ RL } & \multirow{4}{*}{$\begin{array}{l}\text { Individual effects \& } \\
\text { individual linear trends }\end{array}$} & Breitung t-stat & -4.00493 & 0.0000 & Stationary \\
\hline & & IM, Pesaran and Shin W-stat & -2.57524 & 0.0050 & Stationary \\
\hline & & ADF-Fisher Chi-square & 28.5198 & 0.0046 & Stationary \\
\hline & & PP- Fisher Chi-square & 26.8701 & 0.0081 & Stationary \\
\hline \multirow{5}{*}{$\mathrm{CC}$} & \multirow{5}{*}{$\begin{array}{l}\text { Individual effects \& } \\
\text { individual linear trends }\end{array}$} & Levin, Lin\& Chu & -2.40630 & 0.0081 & Stationary \\
\hline & & Breitung t-stat & -1.85697 & 0.0317 & Stationary \\
\hline & & IM, Pesaran and Shin W-stat & -1.18767 & 0.1175 & Non Stationary \\
\hline & & ADF-Fisher Chi-square & 16.3648 & 0.1751 & Non Stationary \\
\hline & & PP- Fisher Chi-square & 15.7449 & 0.2032 & Non Stationary \\
\hline
\end{tabular}

Source: Author's calculation.

After taking the first difference for the variables KF, OT, RL, VA, PS and CC they became stationary at both levels as illustrated in tables $3 \& 4$, this is because the majority of the probability values for unit root test methods are less than 0.05 for the first difference of these variables at both levels, meaning that most null hypotheses of existing unit roots are rejected.

Table 3. Panel unit root test: first difference with individual effects.

\begin{tabular}{|c|c|c|c|c|c|}
\hline Variable & Exogenous variables & Method & Statistic value & Prob. value & decision \\
\hline \multirow{5}{*}{$\mathrm{D}(\mathrm{OT})$} & \multirow{5}{*}{ Individual effects } & Levin, Lin\& Chu & -7.29596 & 0.0000 & Stationary \\
\hline & & IM, Pesaran and Shin W-stat & -5.45373 & 0.0000 & Stationary \\
\hline & & ADF-Fisher Chi-square & 49.0214 & 0.0000 & Stationary \\
\hline & & PP- Fisher Chi-square & 54.2424 & 0.0000 & Stationary \\
\hline & & Levin, Lin\& Chu & -6.86904 & 0.0000 & Stationary \\
\hline \multirow{3}{*}{$\mathrm{D}(\mathrm{KF})$} & \multirow{3}{*}{ Individual effects } & IM, Pesaran and Shin W-stat & -5.47700 & 0.0000 & Stationary \\
\hline & & ADF-Fisher Chi-square & 49.1317 & 0.0000 & Stationary \\
\hline & & PP- Fisher Chi-square & 49.4950 & 0.0000 & Stationary \\
\hline \multirow{4}{*}{$\mathrm{D}(\mathrm{VA})$} & \multirow{4}{*}{ Individual effects } & Levin, Lin\& Chu & -5.78002 & 0.0000 & Stationary \\
\hline & & IM, Pesaran and Shin W-stat & -5.06231 & 0.0000 & Stationary \\
\hline & & ADF-Fisher Chi-square & 47.3460 & 0.0000 & Stationary \\
\hline & & PP- Fisher Chi-square & 129.212 & 0.0000 & Stationary \\
\hline \multirow{4}{*}{$\mathrm{D}(\mathrm{PS})$} & \multirow{4}{*}{ Individual effects } & Levin, Lin\& Chu & -4.47840 & 0.0000 & Stationary \\
\hline & & IM, Pesaran and Shin W-stat & -5.42921 & 0.0000 & Stationary \\
\hline & & ADF-Fisher Chi-square & 49.0916 & 0.0000 & Stationary \\
\hline & & PP- Fisher Chi-square & 302.975 & 0.0000 & Stationary \\
\hline
\end{tabular}




\begin{tabular}{|c|c|c|c|c|c|}
\hline Variable & Exogenous variables & Method & Statistic value & Prob. value & decision \\
\hline \multirow{4}{*}{$\mathrm{D}(\mathrm{RL})$} & \multirow{4}{*}{ Individual effects } & Levin, Lin\& Chu & -14.8739 & 0.0000 & Stationary \\
\hline & & IM, Pesaran and Shin W-stat & -11.8936 & 0.0000 & Stationary \\
\hline & & ADF-Fisher Chi-square & 105.124 & 0.0000 & Stationary \\
\hline & & PP- Fisher Chi-square & 349.126 & 0.0000 & Stationary \\
\hline \multirow{3}{*}{$\mathrm{D}(\mathrm{CC})$} & \multirow{3}{*}{ Individual effects } & Levin, Lin\& Chu & -9.14250 & 0.0000 & Stationary \\
\hline & & IM, Pesaran and Shin W-stat & -8.44079 & 0.0000 & Stationary \\
\hline & & ADF-Fisher Chi-square & 75.4180 & 0.0000 & Stationary \\
\hline
\end{tabular}

Source: Author's calculation.

Table 4. Panel unit root test: first difference with individual effects and individual linear trends.

\begin{tabular}{|c|c|c|c|c|c|}
\hline Variable & Exogenous variables & Method & Statistic value & Prob. value & decision \\
\hline \multirow{4}{*}{$\mathrm{D}(\mathrm{OT})$} & \multirow{4}{*}{$\begin{array}{l}\text { Individual effects \& } \\
\text { individual linear trends }\end{array}$} & Levin, Lin\& Chu & -7.77879 & 0.0000 & Stationary \\
\hline & & Breitung t-stat & -5.05163 & 0.0000 & Stationary \\
\hline & & IM, Pesaran and Shin W-stat & -5.04436 & 0.0000 & Stationary \\
\hline & & PP- Fisher Chi-square & 65.0909 & 0.0000 & Stationary \\
\hline \multirow{4}{*}{$\mathrm{D}(\mathrm{KF})$} & \multirow{4}{*}{$\begin{array}{l}\text { Individual effects \& } \\
\text { individual linear trends }\end{array}$} & Levin, Lin\& Chu & -6.99036 & 0.0000 & Stationary \\
\hline & & Breitung t-stat & -4.53296 & 0.0000 & Stationary \\
\hline & & ADF-Fisher Chi-square & 44.4314 & 0.0000 & Stationary \\
\hline & & PP- Fisher Chi-square & 43.5992 & 0.0000 & Stationary \\
\hline \multirow{5}{*}{$\mathrm{D}$ (VA) } & \multirow{5}{*}{$\begin{array}{l}\text { Individual effects \& } \\
\text { individual linear trends }\end{array}$} & Levin, Lin\& Chu & -5.82177 & 0.0000 & Stationary \\
\hline & & Breitung t-stat & -5.89437 & 0.0000 & Stationary \\
\hline & & IM, Pesaran and Shin W-stat & -4.82377 & 0.0000 & Stationary \\
\hline & & ADF-Fisher Chi-square & 43.2865 & 0.0000 & Stationary \\
\hline & & PP- Fisher Chi-square & 98.0950 & 0.0000 & Stationary \\
\hline \multirow{4}{*}{$\mathrm{D}(\mathrm{PS})$} & \multirow{4}{*}{$\begin{array}{l}\text { Individual effects \& } \\
\text { individual linear trends }\end{array}$} & Levin, Lin\& Chu & -4.72960 & 0.0000 & Stationary \\
\hline & & IM, Pesaran and Shin W-stat & -5.05094 & 0.0000 & Stationary \\
\hline & & ADF-Fisher Chi-square & 43.5145 & 0.0000 & Stationary \\
\hline & & PP- Fisher Chi-square & 55.5908 & 0.0000 & Stationary \\
\hline \multirow{5}{*}{$\mathrm{D}(\mathrm{RL})$} & \multirow{5}{*}{$\begin{array}{l}\text { Individual effects \& } \\
\text { individual linear trends }\end{array}$} & Levin, Lin\& Chu & -12.8123 & 0.0000 & Stationary \\
\hline & & Breitung t-stat & -8.61515 & 0.0000 & Stationary \\
\hline & & IM, Pesaran and Shin W-stat & -10.1321 & 0.0000 & Stationary \\
\hline & & ADF-Fisher Chi-square & 79.8665 & 0.0000 & Stationary \\
\hline & & PP- Fisher Chi-square & 79.1722 & 0.0000 & Stationary \\
\hline \multirow{5}{*}{$\mathrm{D}(\mathrm{CC})$} & \multirow{5}{*}{$\begin{array}{l}\text { Individual effects \& } \\
\text { individual linear trends }\end{array}$} & Levin, Lin\& Chu & -8.20332 & 0.0000 & Stationary \\
\hline & & Breitung t-stat & -7.96325 & 0.0000 & Stationary \\
\hline & & IM, Pesaran and Shin W-stat & -7.16273 & 0.0000 & Stationary \\
\hline & & ADF-Fisher Chi-square & 59.4381 & 0.0000 & Stationary \\
\hline & & PP- Fisher Chi-square & 95.2728 & 0.0000 & Stationary \\
\hline
\end{tabular}

Source: Author's calculation.

Kao panel cointegration test (Engle-Granger based) is used and its result is presented in table 5. There is one deterministic trend specification (individual intercept) in such test. If the probability value is less than $5 \%$, the null hypothesis of no cointegration is rejected, meaning that the study variables are cointegrated. Regarding table 5, the probability value is less than $5 \%$, indicating that the study variables have a long run stable relationship.

Table 5. Kao Residual Cointegration Test.

\begin{tabular}{ll}
\hline ADF t-statistic value & Probability value \\
\hline-4.048214 & 0.0000 \\
\hline
\end{tabular}

Source: Author's calculation.

Based on the results of the unit root and cointegration tests, FMOLS estimation method is used. This method tackles and treats auto correlation and endogeneity in the regressors giving optimal and unbiased estimates. The result of estimation is presented in tables 6 . It is conspicuous that all coefficients carry the expected signs, which is consistent with the economic theory and previous studies. GFC also has a significant negative effect of $2.9 \%$ (at $1 \%$ significance level) on the economic growth of NOEAC.

Table 6. Results of FMOLS estimation (Dependent variable: RGDP growth rate).

\begin{tabular}{lllll}
\hline Variable & Coefficient & Std. Error & t-Statistic & Prob. \\
\hline KF & 0.079146 & 0.020236 & 3.911147 & 0.0002 \\
LF & 0.111382 & 0.033618 & 3.313130 & 0.0014 \\
EF & 0.125050 & 0.019531 & 6.402712 & 0.0000 \\
OT & 0.042526 & 0.005025 & 8.462482 & 0.0000 \\
VA & 0.996768 & 0.249994 & 3.987167 & 0.0002 \\
PS & 0.195609 & 0.183686 & 1.064910 & 0.2904 \\
RQ & 3.165129 & 0.392953 & 8.054732 & 0.0000 \\
GE & 0.015440 & 0.458770 & 0.033656 & 0.9732 \\
RL & 1.978747 & 0.287135 & 6.891350 & 0.0000 \\
\hline
\end{tabular}




\begin{tabular}{lllll}
\hline Variable & Coefficient & Std. Error & t-Statistic & Prob. \\
\hline CC & 2.545204 & 0.347207 & 7.330517 & 0.0000 \\
DM & -2.902618 & 0.120324 & -24.12343 & 0.0000 \\
\hline
\end{tabular}

Source: Author's calculations.

KF: GFCF to GDP, LF: labor force growth rate, OT: openness to trade, EF: economic freedom, VA: voice and accountability, PS: political stability, GE: government effectiveness, RQ: regulatory quality, CC: control of corruption, and RL: rule of law, DM: dummy variable for GFC.

Furthermore, the most effective factors are regulatory quality (RQ), control of corruption (CC) then rule of law (RL) at $1 \%$ significance level, so that a $1 \%$ increase in RQ increases the growth rate of RGDP of these countries by about $3.17 \%$, a $1 \%$ increase in $\mathrm{CC}$ increases such growth by about $2.55 \%$, while a $1 \%$ increase in RL increases economic growth by about $1.98 \%$ during the study period. Political stability (PS) and government effectiveness (GE) have insignificant effects, while voice and accountability (VA) has significant positive effect on the economic growth by about $1 \%$ (at $1 \%$ significance level). The effect of labor force growth rate (LF) is higher than that of gross fixed capital formation (KF); a $1 \%$ increase in LF increases RGDP growth rate by $0.11 \%$, while a $1 \%$ increase in KF increases such growth by about $0.08 \%$ at $1 \%$ significance level. Trade openness contributes slightly to higher growth in these countries, meanwhile, a $1 \%$ increase in economic freedom (EF) increases the economic growth by about $0.13 \%$ at $1 \%$ significance level. Therefore, the null hypothesis of the study is rejected.

\section{Conclusions and Recommendations}

In general, improving the business climate in NOEAC is very important in attracting investments, such countries also can obtain higher credit ratings when they have good and effective public administration and better governance, which can reduce the cost of capital and improve their economic performance. The traditional determinants of economic growth can't positively impact the economic performance if there is underdeveloped, instable, highly corrupted and untrustworthy institutional environment [41]. The main conclusion derived from this study is that political and institutional aspects can play a serious role in the economic progress, and they are responsible for major contribution to economic growth and development. Furthermore, attracting domestic and foreign direct investments, increasing labor and capital productivities, strengthening governance, improving public administration and eradication of corruption have the first priorities in NOEAC.

In order to boost the economic growth in NOEAC, this paper gives the following recommendations: 1- The governments should make real institutional reforms, strengthen governance and fight all kinds of corruption. 2Improving the quality of education and concentrating on developing the expertise and skills of the workforce. 3Establishing specialization in the production of goods in which NOEAC have comparative advantages, diversifying production and sources of income, and not depending only on exporting natural raw materials. 4- Facilitating international trade that permits transition of superior technologies, increases productivity, encourages competition and attracts more international financial flows which will ultimately enhance their economic growth and development.

\section{References}

[1] Kindleberger, Charles p. (1965). Economic Development. 2nd edition, New York: McGraw-Hill.

[2] Solow, R. (1956). A Contribution to the Theory of Economic Growth. Quarterly Journal of Economics, 70 (1), 65-94.

[3] Romer, P. (1986). Increasing Returns and Long Run Growth. Journal of Political Economy, 94 (5), 1002-1037.

[4] Lucas, R. (1988). On the Mechanics of Economic Development. Journal of Monetary Economics, 22, 3-42.

[5] Romer, P. (1990). Endogenous Technological Change. Journal of Political Economy, 98 (5), 71-102.

[6] Barro, R. (1991). Economic Growth in a Cross Section of Countries. Quarterly Journal of Economics, 106 (2), 407- 443.

[7] Barro, R. (1996). Determinants of Economic Growth: A Cross Country Empirical Study. National Bureau Of Economic Research (NBER), Working Paper 5698, 1050 Massachusetts Avenue Cambridge, MA 02138.

[8] Jutting, J. (2003). Institutions and Development: A Critical Review. OECD Development Center, Working Paper 210.

[9] Matthews, R. (1986). The Economics of Institutions and the Sources of Growth. The Economic Journal, 96 (384), 903-918.

[10] Rodrik, D., (2000). Institutions for High-Quality Growth: What They are and How to Acquire Them. NBER Working Paper No. 7540.

[11] Granovetter, M. (1985). Economic Action and Social Structure: The Problem of Embeddedness. American Journal of Sociology, 91 (3), 481-510.

[12] Knack, S. and Keefer, P. (1997). Does Social Capital Have An Economic Impact? A Cross-Country Investigation. Quarterly Journal of Economics, 112 (4), 1251-1288.

[13] Kormendi, R. and Meguire, P. (1985). Macroeconomic Determinants of Growth: Cross-Country Evidence. Journal of Monetary Economics, 16 (4), 141-163.

[14] Lensink, R. (2001). Financial Development, Uncertainty and Economic Growth. De Economist, 149 (3), 299-312.

[15] Podrecca, E. and Carmeci, G. (2001). Fixed Investment and Economic Growth: New Results on Causality. Applied Economics, 33 (2), 177-182.

[16] Lensink, W. and Morrissey, O. (2006). Foreign Direct Investment: Flows, Volatility and the Impact on Growth. Review of International Economics, 14 (3), 478-493.

[17] Brunetti, A., Kisunko G. and Weder, B. (1998). Credibility of Rules and Economic Growth: Evidence from a Worldwide Survey of the Private Sector. The World Bank Economic Review, 12 (3), 353-384. 
[18] Lichtenberg, F. (1992). R \& D Investment and International Productivity Differences. NBER Working Paper, No. 4161.

[19] Ulku, H. (2004). R\&D Innovation and Economic Growth: An Empirical Analysis. IMF Working Paper 185.

[20] Hall, R. and Jones, C. (1999). Why Do Some Countries Produce so Much More Output per Worker Than Others? Quarterly Journal of Economics, 114 (1), 83-116.

[21] Emara, N. and Chiu, I. (2016). The Impact of Governance on Economic Growth: The Case of Middle Eastern and North African Countries. Topics in Middle Eastern and African Economies, 18 (1), 126-144.

[22] Pere, E. (2015). The Impact of Good Governance in the Economic Development of Western Balkan Countries. European Journal of Government and Economics, 4 (1), 25-45.

[23] Dollar, D. and Kraay, A. (2000). Trade, Growth and Poverty. The World Bank Development Research Group, Washington, (mimeo).

[24] Dollar, D. (1992). Outward-Oriented Developing Economies Really Do Grow More Rapidly: Evidence from 95 LDCs, 1976-1985. Economic Development and Cultural Change, 40 (3), 523-544.

[25] AL-Raimony, A. (2011). The Determinants of Economic Growth in Jordan. Abhath Al-Yarmouk, Humanities and Social Sciences Series, 27 (3), 2297-2305.

[26] Razmi, M. J. and Refaei, R. (2013). The Effect of Trade Openness and Economic Freedom on Economic Growth: The Case of Middle East and East Asian Countries. International Journal of Economics and Financial Issues, 3 (2), 376-385.

[27] Lahouij, H. (2016). Does Governance Matter to Economic Growth? Evidence from MENA Countries. Awards for Excellence in Student Research and Creative Activity Documents. 5. http://thekeep.eiu.edu/lib_awards 2016 docs/5.

[28] Petrakos, G., Paschalis, A. and Sotiris, P. (2007). Determinants of Economic Growth: The Experts' View, DYNREG Dynamic Regions in a Knowledge Driven Global Economy Lessons and Policy Implications for the EU WORKING PAPERS, No 20.

[29] Bayar, Y. (2016b). Public Governance and Economic Growth in the Transitional Economies of the European Union. Transylvanian Review of Administrative sciences, No. 48, 518.

[30] Edlund, K. (2017). Does Economic Freedom Affect the Growth Rate? Evidence from Middle-Income Countries.
Bachelor thesis, International Business Program. http://www.divaportal.org/smash/get/diva2:1134907/FULLTE XT01.pdf.

[31] Hsiao, c. (2003). Analysis of Panel Data. 2nd edition, United Kingdom: Cambridge University Press.

[32] World Bank (1992). Governance and Development. Report No. 10650, Washington, DC: The World Bank. World Bank: http://www.worldbank.org/en/search?q=governance\%20indica tors.

[33] Bayar, Y. (2016a). Impact of Openness and Economic Freedom on Economic Growth in the Transition Economies of the European Union. South-Eastern Europe Journal of Economics 1, 7-19.

[34] Emara, N. and Jhonsa, E. (2014). Governance and Economic Growth: The Case of Middle East and North African Countries. Journal of Development and Economic Policies, 16 (1), 47-71.

[35] Bouoiyour, J. and Naimbayel, D. (2012). Economic Growth in Sub-Saharan Africa: Is Governance a Source of Inequality between Countries? Paper presented at the 17th Annual Conference of the African Uganda Econometric Society.

[36] Fayissa, B. and Nsiah, C. (2013). The Impact of Governance on Economic Growth in Africa. Journal of Developing Areas, 47 (1), 91-108.

[37] Orayo, J. and Mose, G. (2016). A Comparative Study on Contribution of Governance on Economic Growth in the East African Community Countries. International Journal of Regional Development, 3 (2), 89-106.

[38] Onyinye, N., Idenyi, O., and Ifeyinwa, A. (2017). Effect of Capital Formation on Economic Growth in Nigeria. Asian Journal of Economics, Business and Accounting, 5 (1), 1-16.

[39] Josheski, D., Lazarov, D., and Koteski, C.(2011). CobbDouglas Production Function Revisited, VAR and VECM Analysis and A note on Fischer/Cobb-Douglass Paradox. Munich Personal RePEc Archive. https://mpra.ub.unimuenchen.de/33576/, 1-22.

[40] Berggren, N. and Jordahl, H. (2005). Does Free Trade Really Reduce Growth? Further Testing Using the Economic Freedom Index. Public Choice, 122 (1-2), 99-114.

[41] Easterly, W. (2001). The Elusive Quest for Growth: Economists' Adventures and Misadventures in the Topics. Cambridge MA: MIT Press. 